\title{
MOLECULAR FINGERPRINTING OF THYROID CANCER CELLS USING LIBRARY OF MOLECULAR RECEPTORS FORMED BY $N$-LIPIDATED PEPTIDES IMMOBILIZED ON CELLULOSE
}

\author{
JUSTYNA FRAC̨CZYK ${ }^{1 *}$, MAŁGORZATA WALCZAK', WALDEMAR BALCERZAK², \\ KATARZYNA POKAJEWICZ ${ }^{3}$, PIOTR WIECZOREK ${ }^{3}$, WOJCIECH MŁYNARSKI ${ }^{4}$, \\ WOJCIECH FENDLER ${ }^{5}$ and ZBIGNIEW J. KAMIŃSKI
}

\author{
'Institute of Organic Chemistry, Lodz University of Technology, Łódź, Poland \\ ${ }^{2}$ Department of General, Gastroenterological and Endocrinological Surgery, Medical University, \\ Wrocław, Poland \\ ${ }^{3}$ Department of Chemistry, University of Opole, Opole, Poland \\ ${ }^{4}$ Department of Pediatrics, Oncology, Hematology and Diabetology, Medical University of Lodz, \\ Łódź, Poland \\ ${ }^{5}$ Department of Biostatistics and Translational Medicine, Medical University of Lodz, Łódź , Poland
}

\begin{abstract}
This paper presents a novel diagnostic method using a library of molecular receptors to assess the composition of healthy and tumorous tissue samples. Molecular receptors were formed by self-organization of $\mathrm{N}$-lipidated peptides attached in the regular fashion via aminophenylamino-1,3,5-triazine linkers to the surface of a cellulose plate. The library was cloned into multiple, identical copies. A new clone was used in each test. The binding process was monitored by staining the discs with Brilliant Black and quantitative color measurement was performed in 256-grade grayscale. Substantial differences in the composition of healthy and tumor samples were observed in most cases. The sharp differences between individual chemical fingerprints were found to depend on the cancer type. Statistical analysis identified the two most useful receptors for diagnosing malignant papillary thyroid cancer.
\end{abstract}

Keywords: cancer markers, chemical receptor, surface modification, molecular mono-layer, immobilized peptides

Cancer is one of the leading causes of death worldwide (1). In 2012, there were 14.1 million new cancer diagnoses and 8.2 million cancer deaths worldwide. Thyroid cancer among women accounted for 230000 of these new cases and for 27000 deaths. Among men, there were 70000 new cases of thyroid cancer and 13000 deaths (2). In most countries, the incidence of thyroid cancer has increased substantially $(3,4)$. If this trend continues, it may become one of the most common cancers $(5,6)$.

As well as by classical methods such as computed tomography (CT) scans and fine needle aspirate (FNA), thyroid cancers can also be diagnosed based on the application of biomarkers. Thyroid cancer biomarkers include the serum protein markers calcitonin (7), thyroglobulin $(8,9)$, galectin-3 (GAL-3), cytokeratin-19, metalloproteinase-1 (TIMP-1) (10) and apolipoprotein C-I, apolipoprotein C-III and haptoglobin alpha-1 chain (11).

It is estimated from the literature (to 2016) that around 30 metabolites have been identified, with significantly different levels of abundance in different types of thyroid tumors. These metabolites include lipids, carboxylic acids, and saccharides. In general, however, it has been concluded that the analysis of multicomponent metabolome signatures is the most promising method for the diagnosis of thyroid cancer (12-16). Monitoring metabolome components is currently recognized as a powerful and multipurpose medical diagnostics tool. It is used to determine health status, disease extension and to monitor the progress of therapy (17-19). Modern analytical methods can provide quantitative and qualitative information on the chemical components of diseases, enabling identification of their specific

* Corresponding author: e-mail: justyna.fraczyk@p.lodz.pl 
markers. Recently, the benefits of this approach have been enhanced by high throughput data collection, leading to the identification of chemical fingerprints for diseases (20).

The development of ultrasensitive multiplexed systems based on fluorescent nanocrystals (quantum dots, QDs) has proven to be effective for early and timely diagnosis of cancers in specific settings (21). Further progress has been spurred by the application of combinatorial chemistry methods, supported by high-throughput screening. This has provided new tools for differentiating the personalized score patterns of healthy and disease-suffering patients, which is particularly helpful in cases where specific markers have not been identified, or when measurements show very large intra-individual variations, thus limiting their usefulness in terms of classical medical diagnosis.

A diverse range of modifications can occur within the metabolic profile of a cancer cell, leading to heterogeneity (22). Currently, there is intense interest in understanding how cancer cells alter cellular metabolism, in whether such changes affect proliferation and tumor growth and in identifying the factors which cause these variations (23-31). Given that characterization of cancer heterogeneity is critical for correct diagnosis and indispensable for successful therapy (32), endeavors have been made to develop new diagnostic platforms based on proteomic analysis (33-35), cancer cell metabolism (36, 37) and regulating mechanisms (38).

In the research described in this paper, preliminary attempts were made to use a library of synthetic receptors to differentiate the metabolite composition of healthy and cancer cells. Our approach is based on the different affinities of the components of the tissue homogenate for the binding sites of molecular receptors. The receptors were formed by the self-organization of $\mathrm{N}$-lipidated oligopeptides immobilized in a regular pattern on a cellulose surface. In previous studies, such constructs had been found capable of differentiating tiny modifications in ligand structures (39) and of selectively binding ligand molecules, thus acting as artificial receptors $(40,41)$. Due to the conformational flexibility of lipidated oligopeptide chains and the presence of diversified functional groups in side chains of amino acid residues, the host-binding pockets formed by supramolecular peptide-peptide interactions are able to adjust their shapes and properties effectively to the requirements of the guest molecule. Varied affinity to tissue homogenates is due to the various quantitative and qualitative composition of the homogenates and to their competitive, highly spe- cific interactions with the molecular receptors, leading to the formation of molecular complexes which are dependent for their stability on the structure of the interacting ligand. Thus, if the binding pattern obtained for patients with a given thyroid cancer is coherent, taking into account both the disease and personal factors, a new diagnostic tool will have been obtained, which could enable the identification of specific biomarkers using less invasive procedures. Moreover, it is possible that this methodology could be extended to other groups of diseases.

\section{MATERIALS AND METHODS}

\section{Synthesis of molecular receptors}

Immobilization of 2,4-dichloro-6-methoxy-1,3,5triazine (DCMT)

140 sheets $(10 \times 5)$ of Whatman-7 filter paper were immersed in $1 \mathrm{M} \mathrm{NaOH}(400 \mathrm{~mL})$ and gently shaken for $15 \mathrm{~min}$. The excess solution was removed, and the wet paper sheets were then soaked in a suspension of finely ground sodium bicarbonate in $1 \mathrm{M}$ of 2,4-dichloro-6-methoxy-1,3,5-triazine (68 g) and THF $(400 \mathrm{~mL})$. The samples were gently shaken for $45 \mathrm{~min}$ at room temperature. The cellulose sheets were then washed with gentle shaking for 10 min in THF $(2 \times 300 \mathrm{~mL})$, acetone $(2 \times 300 \mathrm{~mL})$, acetone: $\mathrm{H}_{2} \mathrm{O} 1: 1(2 \times 400 \mathrm{~mL})$, acetone $(2 \times 400$ $\mathrm{mL})$ and DCM $(300 \mathrm{~mL})$. To remove the remaining solvent, they were left to dry in a vacuum desiccator over $\mathrm{P}_{2} \mathrm{O}_{5}$ and $\mathrm{KOH}$ to constant weight.

Elemental analysis: for cellulose: $\% \mathrm{~N}$ 0.00-0.05; $\% \mathrm{Cl}$ 0.01-0.05, after CDMT immobilization found: $\% \mathrm{~N} 3.64 ; \% \mathrm{Cl} 2.66$. Loading of the cellulose sheets with triazine was calculated from elemental analysis data. Based on a nitrogen content of $2.60 \mathrm{mmol}$ (N)/1 g, loading was calculated as equivalent to $\mathrm{NL}^{\mathrm{w}}$ $=0.87 \mathrm{mmol}$ (triazine) $/ 1 \mathrm{~g}$. Surface loading based on nitrogen content of $31.9 \cdot 10^{-6} \mathrm{~mol}(\mathrm{~N}) / \mathrm{cm}^{2}$ was equivalent to $\mathrm{NL}^{\mathrm{s}}=10.6 \cdot 10^{-6} \mathrm{~mol}($ triazine $) / \mathrm{cm}^{2}$. Loading based on chlorine content was calculated as $\mathrm{ClL}^{\mathrm{w}}=0.75 \mathrm{mmol}(\mathrm{Cl}) / 1 \mathrm{~g}$, equivalent to $\mathrm{ClL}^{\mathrm{s}}=$ $9.2 \cdot 10^{-6} \mathrm{~mol}(\mathrm{Cl}) / \mathrm{cm}^{2}$.

\section{Immobilization of $\boldsymbol{m}$-phenylenediamine}

Cellulose sheets functionalized with 2,4dichloro-6-methoxy-1,3,5-triazine (DCMT) were separated using polypropylene-made mesh dividers and immersed in $1 \mathrm{M}$ solution of $m$-phenylenediamine (43 g) in THF (400 mL), with gentle shaking for $24 \mathrm{~h}$ at room temperature. The sheets were then removed from the $m$-phenylenediamine solution, soaked with dry filter paper and then washed successively with THF $(2 \times 200 \mathrm{~mL})$, DMF 
$(2 \times 200 \mathrm{~mL})$, and with THF $(2 \times 200 \mathrm{~mL})$. The sheets were dried in a vacuum desiccator.

Loading of the first amino acids. Sub-libraries $\{1(A)\},\{2(W)\},\{3(P)\}$

For each sub-library, $\{1(\mathrm{~A})\},\{2(\mathrm{~W})\}$ and $\{3(\mathrm{P})\}$, 46 cellulose sheets were labeled with a graphite pencil as "1", "2" or "3". The Fmoc-protected amino acids (15 mmol), 4-(4,6-dimethoxy-1,3,5-triazin-2yl)-4-methylmorpholinium tetrafluoroborate (DMT/ $\left.\mathrm{NMM} / \mathrm{BF}_{4}\right)(4.92 \mathrm{~g}, 15 \mathrm{mmol})$ and $\mathrm{HOBt}(2.28 \mathrm{~g}, 15$ $\mathrm{mmol})$ were dissolved in DMF (50 $\mathrm{mL})$, and NMM ( $3.3 \mathrm{~mL}, 30 \mathrm{mmol}$ ) was added. The functionalized cellulose sheets loaded with Fmoc-L-protected amino acids were separated using polypropylenemade mesh dividers. They were immersed in the mixture of reagents with gentle shaking for $24 \mathrm{~h}$. The excess acylating reagent was removed. The sheets were then washed successively in DMF $(3 \times$ $100 \mathrm{~mL})$ and DCM $(3 \times 50 \mathrm{~mL})$ with gentle shaking. They were dried in a vacuum desiccator.

The same procedure was used for the preparation of sub-library $\{1\}$ using Fmoc-L-Ala-OH (4.94 g, $15 \mathrm{mmol})$, sub-library $\{2\}$ using Fmoc-LTrp(Boc)-OH (6.40 g, $15 \mathrm{mmol})$ and for sub-library \{3\} using Fmoc-L-Pro-OH (5.06 g, 15 mmol).

\section{Evaluating loading of first amino acids on cellu- lose}

Loading of the first amino acids on cellulose was evaluated based on an extinction measurement of the absorbance at $301 \mathrm{~nm}$ of dibenzofulvene, which forms during the removal of the Fmoc group. Quantitative assessment of the first amino acids immobilized on cellulose was performed based on the equation:

$$
\left[\mathrm{mmol} / \mathrm{g}_{\text {cellulose }}\right]=\frac{A_{301}}{7800} \times \frac{V}{m_{\text {cellulose }}}
$$

where $\mathrm{A}$ is the absorbance of dibenzofulvene, $\mathrm{V}$ is the volume of the flask [mL] and $\mathrm{m}$ is the mass of cellulose $[\mathrm{g}]$.
Two independent measurements were performed for each sub-library, $\{1\},\{2\}$ and $\{3\}$, using two fragments of each cellulose sheet. The results are shown in Table 1.

\section{Removal of Fmoc-protecting group}

For each sub-library, $\{1\},\{2\}$ and $\{3\}, 45$ sheets were immersed in $25 \%$ solution of piperidine in DMF (400 mL) and gently shaken for $20 \mathrm{~min}$. They were then washed with DMF $(3 \times 200 \mathrm{~mL})$ and DCM $(1 \times 200 \mathrm{~mL})$ and used immediately in the next synthetic stage.

\section{Incorporation of the second amino acid}

For each sub-library, $\{1\},\{2\}$ and $\{3\}$, consisting of a set of 40 sheets, every other sheet was labeled with graphite pencil as $\{101\},\{102\},\{103\}$, $\{104\},\{105\},\{106\},\{107\},\{108\},\{109\}$, $\{110\},\{111\},\{112\},\{113\},\{114\},\{115\},\{116\}$, $\{117\},\{118\},\{119\},\{120\}$ for Ala, $\{201\},\{202\}$, $\{203\},\{204\},\{205\},\{206\},\{207\},\{208\},\{209\}$, $\{210\},\{211\},\{212\},\{213\},\{214\},\{215\},\{216\}$, $\{217\},\{218\},\{219\},\{220\}$ for Trp, and $\{301\}$, $\{302\},\{303\},\{304\},\{305\},\{306\},\{307\},\{308\}$, $\{309\},\{310\},\{311\},\{312\},\{313\},\{314\},\{315\}$, $\{316\},\{317\},\{318\},\{319\},\{320\}$ for Pro. The sheets in the sub-library were then separated using polypropylene-made mesh dividers and immersed with gentle shaking for $24 \mathrm{~h}$ in a solution of FmocL-protected amino acid (5 mmol), DMT/NMM/ $/ \mathrm{BF}_{4}$ (1.65 g, $5 \mathrm{mmol})$ and HOBt $(0.76 \mathrm{~g}, 5 \mathrm{mmol})$ in DMF (30 mL), to which NMM (1.1 mL, $10 \mathrm{mmol})$ was added. The excess acylating reagent was removed, and the sheets were washed successively by shaking in DMF $(3 \times 100 \mathrm{~mL}$ and DCM $(3 \times 100$ $\mathrm{mL})$. They were dried in a vacuum desiccator. The same procedure was repeated using successively all 20 natural amino acids:

Fmoc-L-Ala-OH (1.646 g, $5.0 \mathrm{mmol})$ and sheets marked as: 101, 201, 301.

Table 1. Loading of the first amino acids on cellulose.

\begin{tabular}{|c|c|c|c|}
\hline Amino acids & $\mathrm{A}_{301}$ & $\mathrm{~m}_{\text {cellulose }}[\mathrm{g}]$ & Loading $[\mathrm{mmol} / \mathrm{g}]$ \\
\hline 1-Ala & 0.501 & 0.0122 & 0.132 \\
\hline 2-Ala & 0.492 & 0.0121 & 0.130 \\
\hline 1-Pro & 0.554 & 0.0217 & 0.081 \\
\hline 2-Pro & 0.547 & 0.0222 & 0.079 \\
\hline 1-Trp & 0.499 & 0.0131 & 0.122 \\
\hline 2-Trp & 0.499 & 0.0130 & 0.123 \\
\hline
\end{tabular}


Fmoc-L-Phe-OH (1.937 g, $5.0 \mathrm{mmol})$ : and sheets marked as: 102, 202, 302.

Fmoc-L-Leu-OH $(1.767 \mathrm{~g}, 5.0 \mathrm{mmol})$ and sheets marked as: 103, 203, 303 .

Fmoc-L-Ile-OH $(1.767 \mathrm{~g}, 5.0 \mathrm{mmol})$ and sheets marked as: 104, 204, 304.

Fmoc-L-Val-OH (1.697 g, $5.0 \mathrm{mmol})$ and sheets marked as: 105, 205, 305 .

Fmoc-L-Met-OH $(1.857 \mathrm{~g}, 5.0 \mathrm{mmol})$ and sheets marked as: 106, 206, 306.

Fmoc-L-Cys(Trt)-OH (2.928 g, $5.0 \mathrm{mmol})$ and sheets marked as: 107, 207, 307.

Fmoc-L-Ser(tBu)-OH (1.917 g, $5.0 \mathrm{mmol})$ and sheets marked as: 108, 208, 308.

Fmoc-L-Tyr(tBu)-OH (2.298 g, $5.0 \mathrm{mmol})$ and sheets marked as 109, 209, 309.

Fmoc-L-Thr(tBu)-OH (1.987 g, $5.0 \mathrm{mmol})$ and sheets marked as: $110,210,310$.

Fmoc-L-Glu(OtBu)-OH (2.127 g, $5.0 \mathrm{mmol})$ and sheets marked as: $111,211,311$.

Fmoc-L-Asp(OtBu)-OH (2.057 g, $5.0 \mathrm{mmol})$ and sheets marked as: $112,212,312$.

Fmoc-L-Gln(Trt)-OH (3.053 g, $5.0 \mathrm{mmol})$ and sheets marked as: $113,213,313$.

Fmoc-L-Asn(Trt)-OH (2.983 g, $5.0 \mathrm{mmol})$ and sheets marked as: 114, 214, 314.

Fmoc-L-His(Trt)-OH (3.098 g, $5.0 \mathrm{mmol})$ and sheets marked as: $115,215,315$.

Fmoc-L-Lys(Boc)-OH (2.342 g, $5.0 \mathrm{mmol})$ and sheets marked as:116, 216, 316.

Fmoc-L-Pro-OH (1.687 g, $5.0 \mathrm{mmol})$ and sheets marked as: 117, 217, 317.

Fmoc-L-Trp(Boc)-OH (2.132 g, $5.0 \mathrm{mmol})$ and sheets marked as: 118, 218, 318 .

Fmoc-L-Arg(Pbf)-OH (3.244 g, $5.0 \mathrm{mmol})$ and sheets marked as: $119,219,319$.

Fmoc-Gly-OH $(1.486 \mathrm{~g}, 5.0 \mathrm{mmol})$ and sheets marked as: $120,220,320$

\section{Removal of Fmoc-protecting group}

Each sub-library of dipeptides was immersed in $25 \%$ solution of piperidine in DMF $(400 \mathrm{~mL})$ and shaken gently for $20 \mathrm{~min}$. They were washed with DMF $(3 \times 200 \mathrm{~mL})$ and DCM $(1 \times 200 \mathrm{~mL})$ then used immediately in the next stage of synthesis.

\section{Incorporation of carboxylic acid residue}

Carboxylic acid $(20 \mathrm{mmol})$ and NMM $(1.2 \mathrm{~mL}$, $10 \mathrm{mmol}$ ) were added to a solution of DMT/ $\mathrm{NMM} /$ TosO $(8.26 \mathrm{~g}, 20 \mathrm{mmol})$ in DCM $(75 \mathrm{~mL})$ cooled to $0-5^{\circ} \mathrm{C}$ with vigorous stirring. Stirring was continued at $0-5^{\circ} \mathrm{C}$ for $4 \mathrm{~h}$. Each sub-library of 60 sheets, separated by polypropylene-made mesh dividers, was then immersed in the suspension with gentle shaking at room temperature for $24 \mathrm{~h}$. The sheets were soaked and washed with DCM $(4 \times 200$ $\mathrm{mL})$, DMF $(2 \times 200 \mathrm{~mL})$ and DCM $(2 \times 200 \mathrm{~mL})$. Acylation using (9Z, 12R)-12-hydroxyoctadec-9enoic (ricinoleic acid) (A) $(5.97 \mathrm{~g}, 20.0 \mathrm{mmol})$ and octadecanoic acid (stearic acid) (B) (5.69 g, 20.0 mmol) yielded 120 components.

\section{Removal of side chain protecting groups}

The functionalized cellulose sheets were treated with $400 \mathrm{~mL}$ solution of TFA in DCM $(50 \% \mathrm{v} / \mathrm{v})$ in the presence of triisopropylsilane (TIS) $(2 \% \mathrm{v} / \mathrm{v})$ and water $(3 \% \mathrm{v} / \mathrm{v})$ for $2 \mathrm{~h}$. They were then washed by successive immersion in DCM $(2 \times 200 \mathrm{~mL})$, EtOH $(2 \times 200 \mathrm{~mL})$ and DCM $(2 \times 200 \mathrm{~mL})$ with gentle shaking. They were dried in a desiccator.

\section{Cloning of the library}

The library obtained was cloned into 80 copies by dividing the sheets into uniform disks $6 \mathrm{~mm}$ in diameter. Each disk was individually marked using a graphite pencil with the label of the parent sheet. The disks were treated with a solution of phosphate buffer at $\mathrm{pH} 7$ for $15 \mathrm{~min}$ and then dried in a vacuum desiccator.

\section{Biological samples}

Thyroid samples were collected from 19 patients after scheduled thyroidectomies at the Department of General, Gastroenterological and Endocrinological Surgery, Medical University of Wroclaw. Two thyroid samples were taken from each patient. The first sample was taken from tumor tissue and the second from healthy tissue from tumor-free lobes. The samples were collected from 19 patients with different thyroid conditions.

To reduce the personalized effects, all the data obtained for individual patients were assembled as sets of results defined according to the cancer type, as diagnosed after surgery. The samples were assembled into 5 groups: four groups with benign tumor types (nodular goiter, benign thyroiditis chronica, benign Huerthle cell adenoma and benign struma nodosa) and one group with malignant papillary thyroid cancer.

All the samples were transported in liquid nitrogen and stored in deep-freeze $\left(-72^{\circ} \mathrm{C}\right)$ until processing. Each tissue sample (100 mg) was homogenized in $0.05 \mathrm{M}$ phosphate buffer $\mathrm{pH} 6.8(1 \mathrm{~mL})$ in an ice bath. The homogenate was centrifuged at $7840 \mathrm{G}$ $\left(10 \mathrm{~min}, 3^{\circ} \mathrm{C}\right)$. Supernatant $(400 \mu \mathrm{L})$ was ultrafiltered at $13400 \mathrm{G}$ for $95 \mathrm{~min}$ at $3^{\circ} \mathrm{C}$ using a Microcon YM-3 centrifugal filter unit (Millipore, Bedford, USA). Ultrafiltration was repeated with a 


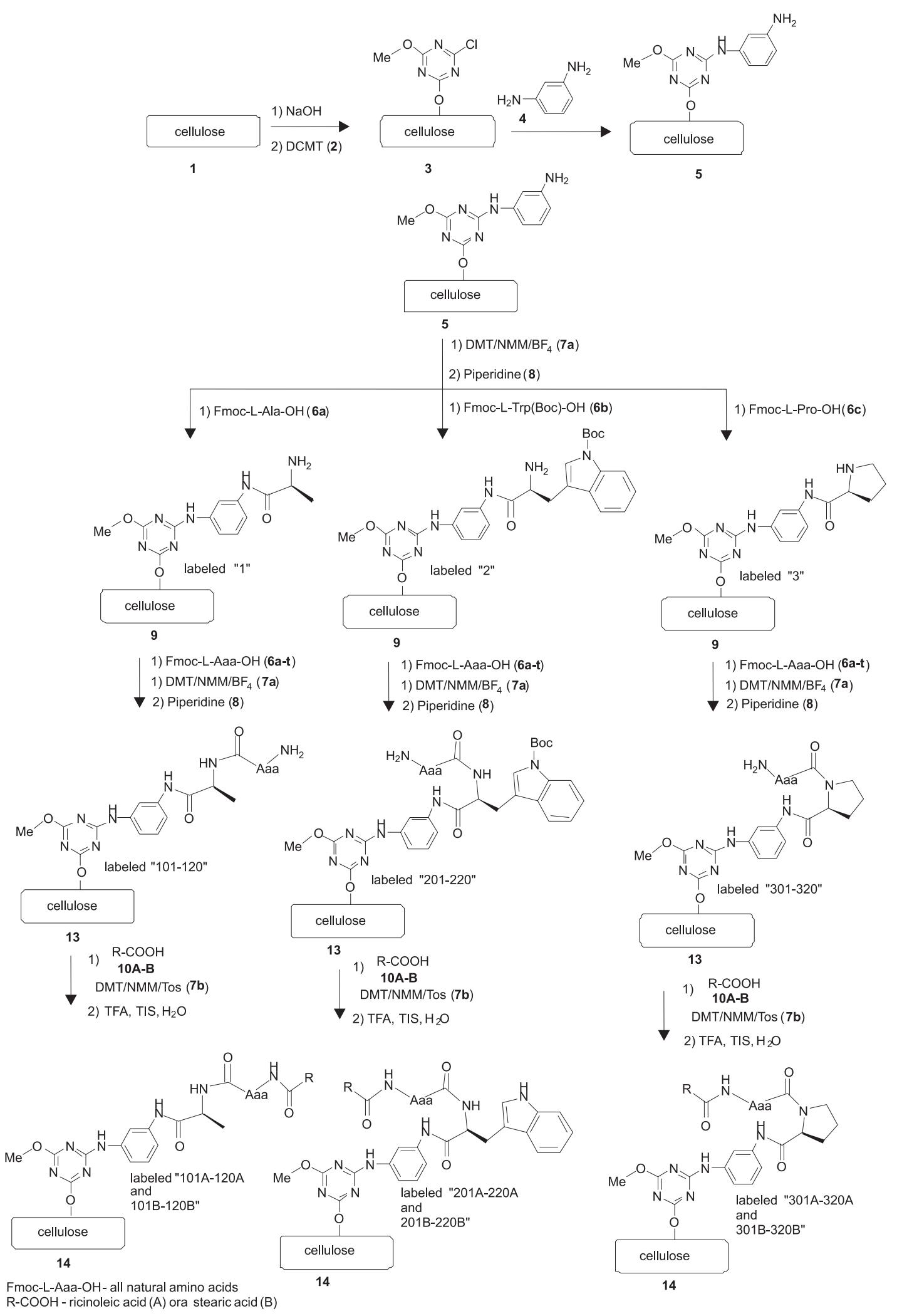

Scheme 1. Synthesis of receptor library $\mathbf{1 4}$ formed by self-organization of $N$-acylated dipeptides immobilized on cellulose surface 
second $400 \mu \mathrm{L}$ volume of supernatant. Low molecular weight fractions from both portions were mixed in a $1.5 \mathrm{~mL}$ Eppendorf tube, frozen in liquid nitrogen, lyophilized and stored in a freezer $\left(-18^{\circ} \mathrm{C}\right)$. Before analysis, the lyophilizate was dissolved in water $(0.7 \mathrm{~mL})$. The solution was immediately deposited on a peptide library ( $5 \mu \mathrm{L}$ on each disc).

\section{Binding of tissue homogenate components to molecular receptor pockets}

Before docking components of the tissue homogenate, the library of molecular receptors was treated with $\mathrm{pH} 7$ phosphate buffer for $15 \mathrm{~min}$. The disks were then washed with distilled water $(3 \times 50 \mathrm{~mL})$ and dried in a vacuum desiccator. Both the healthy and unhealthy tissue homogenates were suspended in $\mathrm{pH} 7$ phosphate buffer. The 120 cloned disks from the library were immersed in the suspension with gentle shaking for $15 \mathrm{~min}$. The excess homogenate was removed by washing with aqueous $0.9 \% \mathrm{NaCl}$ solution $(2 \times 50 \mathrm{~mL})$ and distilled water $(1 \times 50$ $\mathrm{mL})$. The disks were dried in vacuum desiccator for $24 \mathrm{~h}$. They were then immersed again in $0.001 \mathrm{M}$ solution of Brilliant Black in methanol $(50 \mathrm{~mL})$, shaken for $20 \mathrm{~min}$ and washed thoroughly with methanol $(5 \times 50 \mathrm{~mL})$. The disks were dried in a vacuum desiccator and scanned.

Scanning was performed in a 24-bit RGB color space. The images obtained were converted into 256-bit grayscale, then processed using the ImageQuant program. For each disk, an average value was given for "gray" coloration, showing differences in interaction between the binding pockets of the molecular receptors and the reporter dye. The ability of the molecular receptors to interact with colorless compounds of low molecular weight in the tissue homogenates $\left(I_{D}\right)$ was calculated as the difference between the intensity of coloration by the reporter dye $\left(I_{D r d}\right)$ and the intensity of coloration after treatment with colorless analyte $\left(I_{D a}\right)$ followed by the reporter dye:

$$
I_{D}=I_{\text {Drd }}-I_{D a}
$$

where $I_{D}$ is the intensity of ligand binding measured by coloration in 256-bit grayscale, $\mathrm{I}_{\mathrm{Drd}}$ is the intensity of coloration with reporter dye and $\mathrm{I}_{\mathrm{Da}}$ is the intensity of dying after treatment with analyte followed by reporter dye. $I_{D}$ is thus proportional to the amount of ligand bound to the receptor. The same procedure and calculations were used for the analytes taken from all patients, including healthy and cancerous tissues - i.e., the $I_{D}{ }^{h}$ for healthy tissue and $I_{D}{ }^{c}$ for cancer tissue were calculated for each receptor.

\section{RESULTS AND DISCUSSION}

All Proteinogenic amino acids were used as substrates in the preparation of molecular receptors. This approach ensured the synthesis of molecular receptors capable of differentiating between healthy and cancerous tissue homogenates. The receptor layer was prepared using a stepwise process, following procedures described elsewhere (42). The order of the steps was as follows: functionalization of cellulose (1) with a 1,3,5-triazine derivative $\mathbf{2}$; reaction with $m$-phenylenediamine (4); coupling with $N$-Fmoc-protected Ala, Pro or Trp; deprotec-

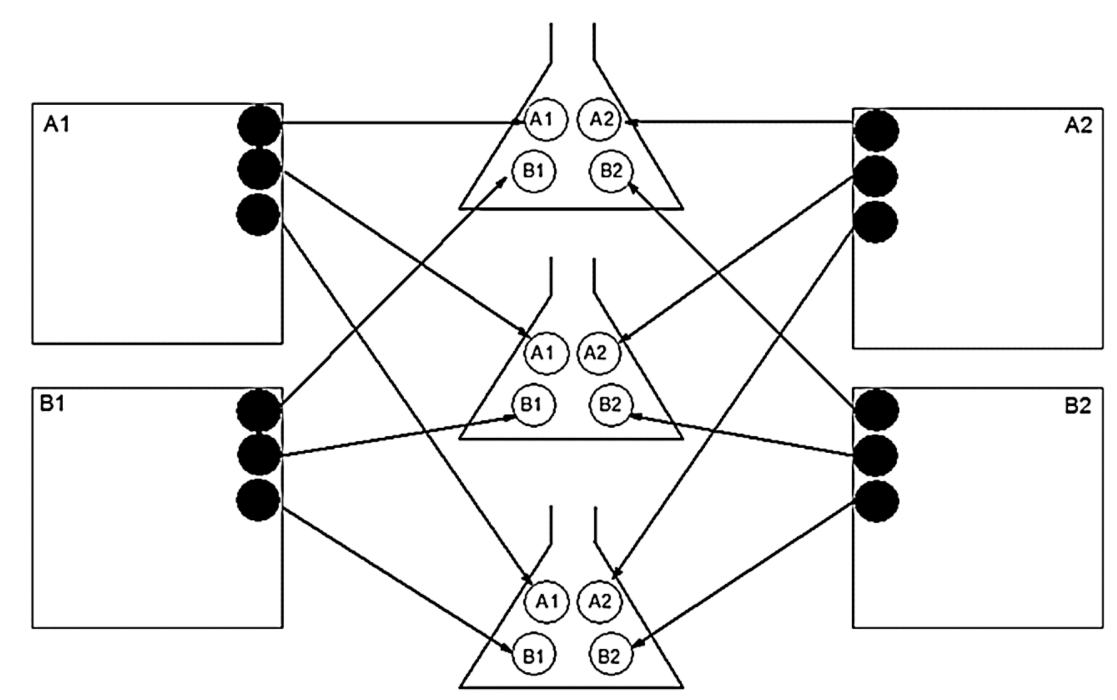

Scheme 2. Methodology for cloning molecular receptor libraries 
tion of the $\mathrm{N}$-terminus; coupling with all Fmoc-protected proteinogenic amino acids separately; acylation with appropriate carboxylic acids 10A-B (see Scheme 1).

Each constituent of the library was prepared on a separate cellulose plate. The library was then cloned to produce 120 copies by cutting the cellulose plates into identical discs $6 \mathrm{~mm}$ in diameter. Each disc was marked with a unique label on the reverse-side using a graphite pencil (see Scheme 2). This procedure guaranteed access to identical copies of the library and eliminated any discrepancies arising from accidental modification during receptor synthesis.

As anticipated, the cloned libraries of receptors gave spread patterns of responses for cancer patients. Analysis of the results showed that, in all cases (tissue homogenates of 19 patients diagnosed with malignant or benign thyroid cancers), an individual pattern of responses was obtained for each patient.

To reduce the personalized effects, all the data obtained for individual patients were assembled as sets of results defined according to the cancer type, as diagnosed after surgery. Thus, the cancerous and healthy tissue samples collected from 19 patients were assembled into 5 groups: four groups with benign tumor types (nodular goiter, benign thyroiditis chronica, benign Huerthle cell adenoma and benign struma nodosa) and one group with malignant papillary thyroid cancer. For each receptor in each group, the intensity of ligand binding was calculated based on coloration in 256-bit grayscale after treatment with healthy $\left(\mathrm{I}_{\mathrm{D}}{ }^{\mathrm{h}}\right)$ and cancerous tissue $\left(\mathrm{I}_{\mathrm{D}}{ }^{\mathrm{c}}\right)$. Standard deviation values (SD) were also calculated for all $I_{D}$ samples, collected from patients suffering from the different types of cancers. The low SD values in all cases indicate the high repeatability of the synthesis of molecular receptors, docking of the tissue homogenates and competent binding of the reporter dye.

The most significant differences in ligand binding between cancer and healthy tissue (up to 2-fold higher intensity) were observed in the case of tissue homogenates from patients suffering from benign struma nodosa. In all cases, a significantly higher intensity of staining $\left(\mathrm{I}_{\mathrm{D}}\right)$ was observed for tumor tissue homogenates.

In the case of docking with homogenate of healthy tissue, the lowest intensity of coloration, at $\mathrm{I}_{\mathrm{D}}{ }^{\mathrm{h}}=9$, was observed for molecular receptor 312A, while the highest was for molecular receptor $309 \mathrm{~A}$, at $I_{D}{ }^{h}=71$. The average $I_{D}{ }^{h}$ value for the whole library docking with healthy homogenate was 31 . In the case of docking with homogenate from benign struma nodosa tissue, the lowest coloration value $\mathrm{I}_{\mathrm{D}}{ }^{\mathrm{c}}$ $=10$ was observed for field $\mathbf{3 1 6 B}$, while the highest coloration value $I_{D}{ }^{c}=157$ was observed for molecular receptor 205A. The average $I_{D}{ }^{c}$ value for the whole library treated with tumor issue was 79 . The SDs calculated from the results of triplicate binding experiments on $\mathrm{I}_{\mathrm{D}}$ samples from patients with benign struma nodosa were very low. The highest SD value, at \pm 1.515 , was observed for field $112 \mathrm{~A}$, treated with healthy tissue homogenate. The lowest, SD $=0.702$, was observed for $120 \mathrm{~A}$, also treated with healthy tissue homogenate.

Differences were observed in terms of the intensity with which the receptors docked cancerous and healthy tissue homogenates. The ligands showed greater ability to bind to normal tissue $\left(\mathrm{I}_{\mathrm{D}}{ }^{\mathrm{h}}>\mathrm{I}_{\mathrm{D}}{ }^{\mathrm{c}}\right)$, and the differences in coloration were smaller. The lowest intensity of coloration $\left(\mathrm{I}_{\mathrm{D}}{ }^{\mathrm{h}}=52\right)$ was observed for field 108B, while most intense staining $\left(\mathrm{I}_{\mathrm{D}}{ }^{\mathrm{h}}=\right.$ 126) was observed for molecular receptor 306A. The mean value for all fields treated with normal, healthy tissue homogenate was 88.8.

For the homogenate derived from benign Huerthle cell adenoma tissue, the lowest coloring intensity was observed for field 116B $\left(I_{D}{ }^{c}=29.5\right)$. The most intense coloration was observed for field 206A $\left(I_{D}{ }^{c}=103\right)$. The mean value for all fields treated with tumor tissue homogenate was 75.6. For benign Huerthle cell adenoma, the lowest SD value was \pm 0.812 for molecular receptor 202B treated with homogenate from healthy tissue, the highest $\mathrm{SD}$ was \pm 1.458 for receptor 215A.

A similar correlation was observed in studies with samples from patients suffering from benign thyroiditis chronica and nodular goiter thyroid cancer. In both instances, staining of healthy tissues was more intense compared to tumor-altered tissues.

For benign thyroiditis chronica homogenate derived from healthy tissue, the lowest coloration value was 45 for molecular receptor $115 \mathrm{~A}$ and the highest 147 for 309A. The average value for the coloration of all fields treated with homogenate from healthy tissue was 65.4. For the tumor tissue homogenate, the lowest value was $I_{D}{ }^{c}=11$ for receptor $118 \mathrm{~B}$ and the highest $\mathrm{I}_{\mathrm{D}}{ }^{\mathrm{c}}=127$ for $310 \mathrm{~A}$. The average intensity of staining for all fields treated with tumor tissue homogenate was 45.0. The lowest $\mathrm{SD}=0.861$ was for receptor $308 \mathrm{~B}$ treated with homogenate derived from healthy tissue, and the highest $\mathrm{SD}=1.487$ was for receptor 201B after docking with homogenate of healthy tissue.

In the case of nodular goiter thyroid cancer docking with healthy tissue homogenate, the lowest 
(a)

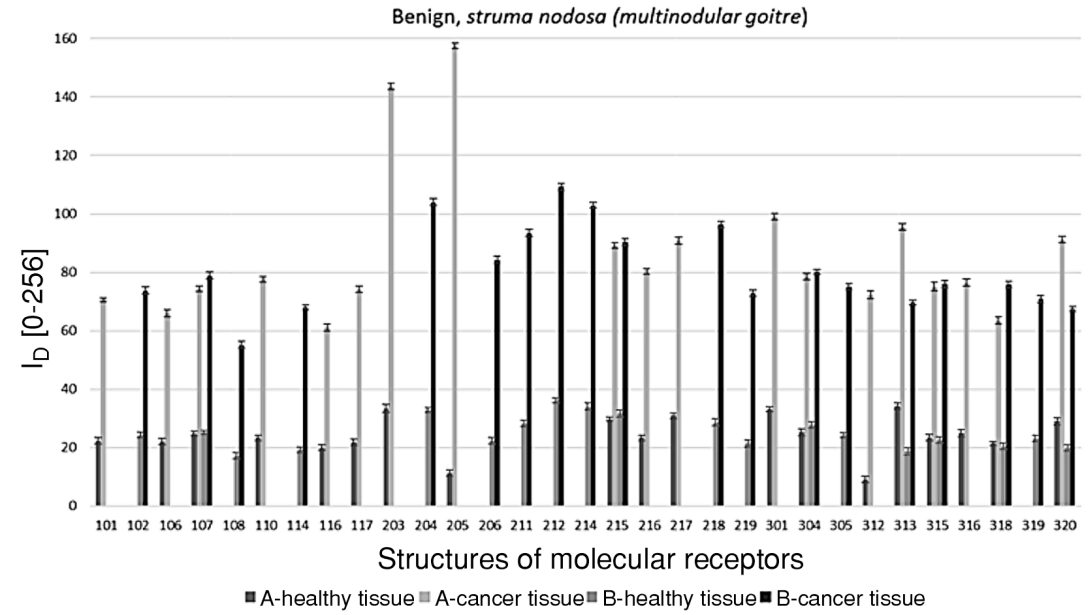

(b)
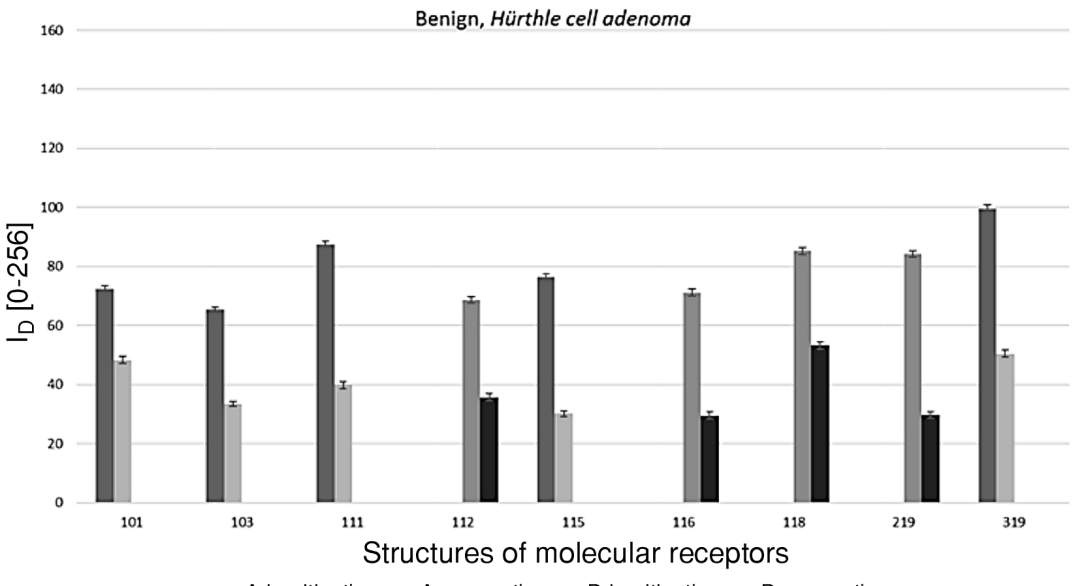

(c)

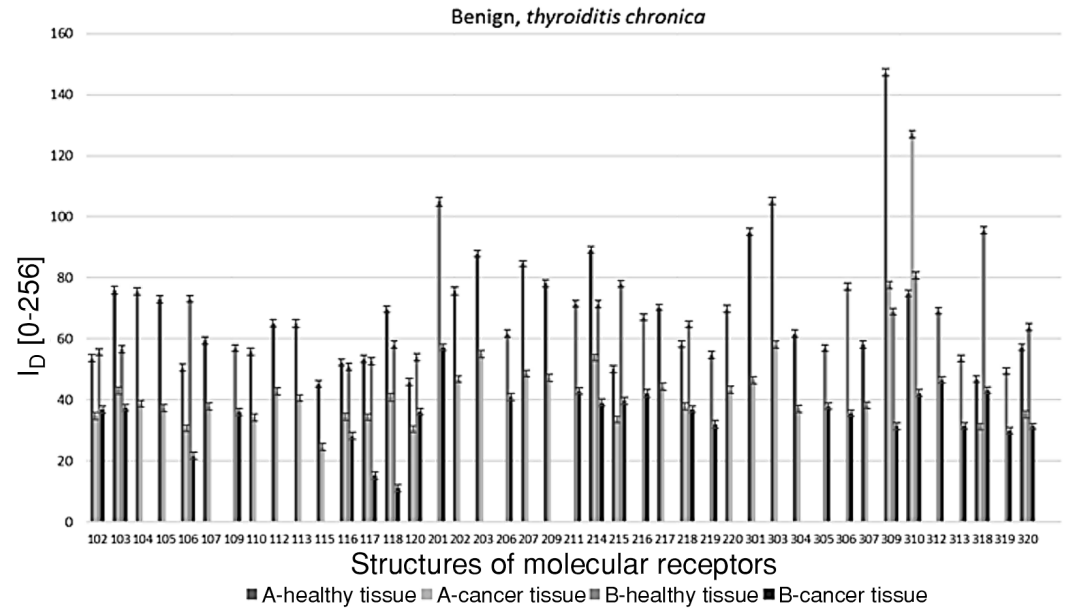

Figure 1. Binding pattern and intensity of coloration of selected molecular receptors treated with tissue samples collected from patients suffering from: (a) benign, struma nodosa (multinodular goiter); (b) benign, Hürthle cell adenoma; (c) benign, Thyroiditis chronica; (d) benign, Nodular goiter; (e) malignant, Papillary thyroid cancer (A - refers to peptides acylated by (9Z, 12R)-12-hydroxyoctadec-9-enoic acid residue (ricinoleic acid); $\mathrm{B}$ - acylated with octadecanoic acid residue (stearic acid) 
(d)

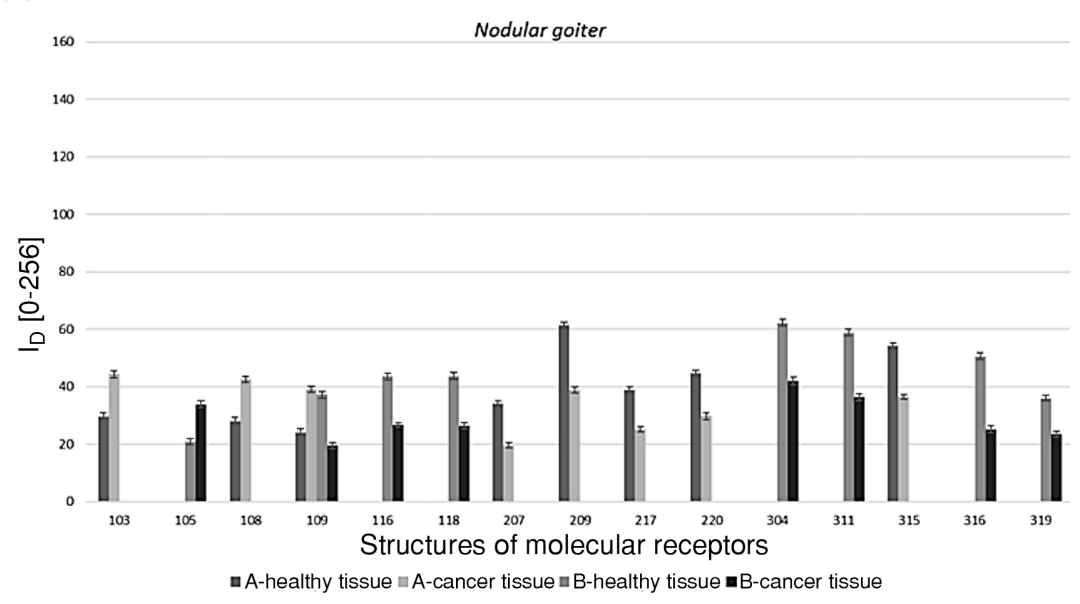

(e)

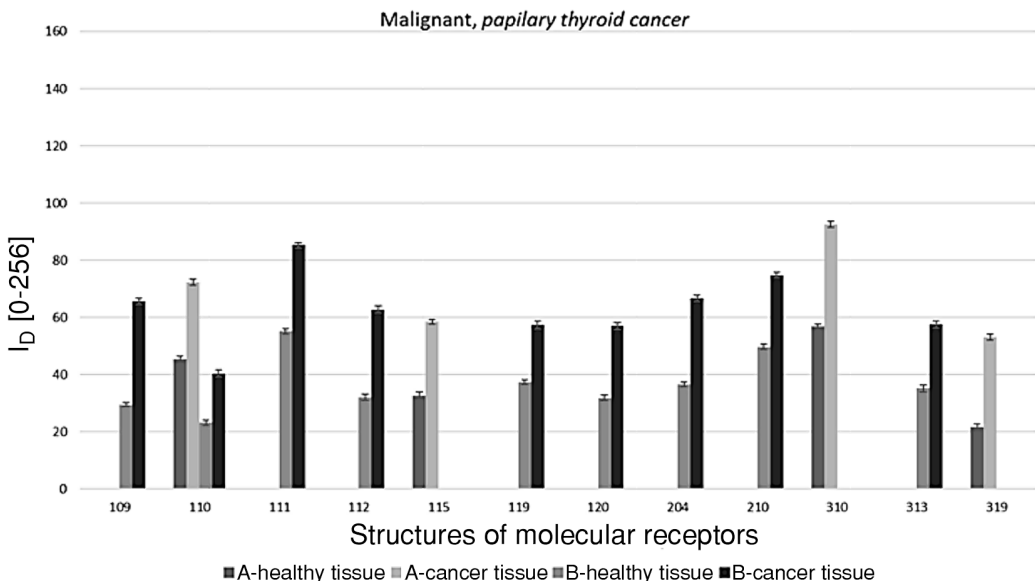

Figure 1. Continued

$I_{D}{ }^{h}=21$ was for receptor $101 \mathrm{~A}$, while the highest $I_{D}{ }^{h}$ $=83$ was for field 310A. The average for all the fields treated with homogenate of healthy tissue was 50.8. The average intensity of staining for the whole library treated with homogenate from healthy tissue was 50.8 .

For homogenate from nodular goiter thyroid cancer, the lowest intensity of coloration was for receptor $316 \mathrm{~B}$ at $\mathrm{I}_{\mathrm{D}}{ }^{\mathrm{c}}=25$. The most intense staining was for field 201B $\left(I_{D}{ }^{c}=80\right)$. The average intensity of staining for the whole library treated with this cancer tissue homogenate was 44.6. The lowest SD $=0.852$ was for receptor 119A treated with homogenate derived from healthy tissue, and the highest $\mathrm{SD}=1.248$ for receptor $113 \mathrm{~A}$ after docking with homogenate of healthy tissue.
Binding between the receptors and tissue homogenates of patients with malignant papillary thyroid cancer was significantly weaker. The $I_{D}$ value did not exceed 95 for any of the fields in the library. More intense staining of the discs was observed in the case of tumor tissue homogenate. The lowest value $\left(I_{D}{ }^{h}=21\right)$ for discs treated with healthy tissue homogenate was observed for receptor $118 \mathrm{~B}$ and the most intense coloration was for field 309A $\left(I_{D}{ }^{h}=89\right)$. The average value for all elements of the library treated with homogenate from healthy tissue was 58.0. In the case of docking with homogenate from tumor tissue, the weakest coloration $\left(\mathrm{I}_{\mathrm{D}}{ }^{\mathrm{c}}=30\right)$ was observed for field $118 \mathrm{~B}$ and the most intense coloration was observed for field 310A $\left(I_{D}{ }^{c}=92\right)$. The average value for the whole 
library treated with homogenate from malignant papillary thyroid cancer tissue was 66.5 . The lowest $\mathrm{SD}=0.509$ was found for receptor 209A treated with homogenate derived from healthy tissue, and the highest $\mathrm{SD}=1.809$ for receptor 305A after docking with homogenate of the cancer tissue.

In the next stage of our study, the molecular receptors most capable of distinguishing abnormal homogenates from healthy tissue were selected. Obviously, any receptors associated with similar values for $I_{D}{ }^{c}$ and $I_{D}{ }^{h}$ were considered unsuitable for the differentiation of healthy from cancerous tissue. Of most interest were receptors with highly differentiated $\mathrm{I}_{\mathrm{D}}{ }^{\mathrm{c}}$ and $\mathrm{I}_{\mathrm{D}}{ }^{\mathrm{h}}$ values. The minimum difference was defined as $\mathrm{I}_{\mathrm{D}}{ }^{\mathrm{c}} / \mathrm{I}_{\mathrm{D}}{ }^{\mathrm{h}}$ or $\mathrm{I}_{\mathrm{D}}{ }^{\mathrm{h}} / \mathrm{I}_{\mathrm{D}}{ }^{\mathrm{c}}>1.5$.
The sharpest differences in color intensity were between samples taken from patients suffering from benign struma nodosa (multinodular goiter) (Fig. 1). Therefore, for this tumor, it was decided to analyze data only when the difference in color intensity between tissues $\left(\mathrm{I}_{\mathrm{D}}{ }^{\mathrm{c}} / \mathrm{I}_{\mathrm{D}}{ }^{\mathrm{h}}\right.$ or $\left.\mathrm{I}_{\mathrm{D}}{ }^{\mathrm{h}} / \mathrm{I}_{\mathrm{D}}{ }^{\mathrm{c}}\right)$ exceeded 3 (three times higher values for staining). Based on this criterion, 37 receptors were selected (Fig. 1a), although in 6 cases their $I_{D}$ varied only in terms of the structure of the lipid. The 6 structures were: $107 \mathrm{~A} / \mathbf{B}$, 215A/B, 313A/B, 315A/B, 318A/B and 320A/B. The sharpest difference in the intensity of staining between samples of healthy and cancer tissue (14.2) was observed for 205A ( $N$-ricinoleyl-Val-Trp-NH$\mathrm{C}_{6} \mathrm{H}_{4}-\mathrm{NH}-\mathrm{C}_{4} \mathrm{H}_{3} \mathrm{~N}_{3} \mathrm{O}$-cellulose). Eight-fold higher

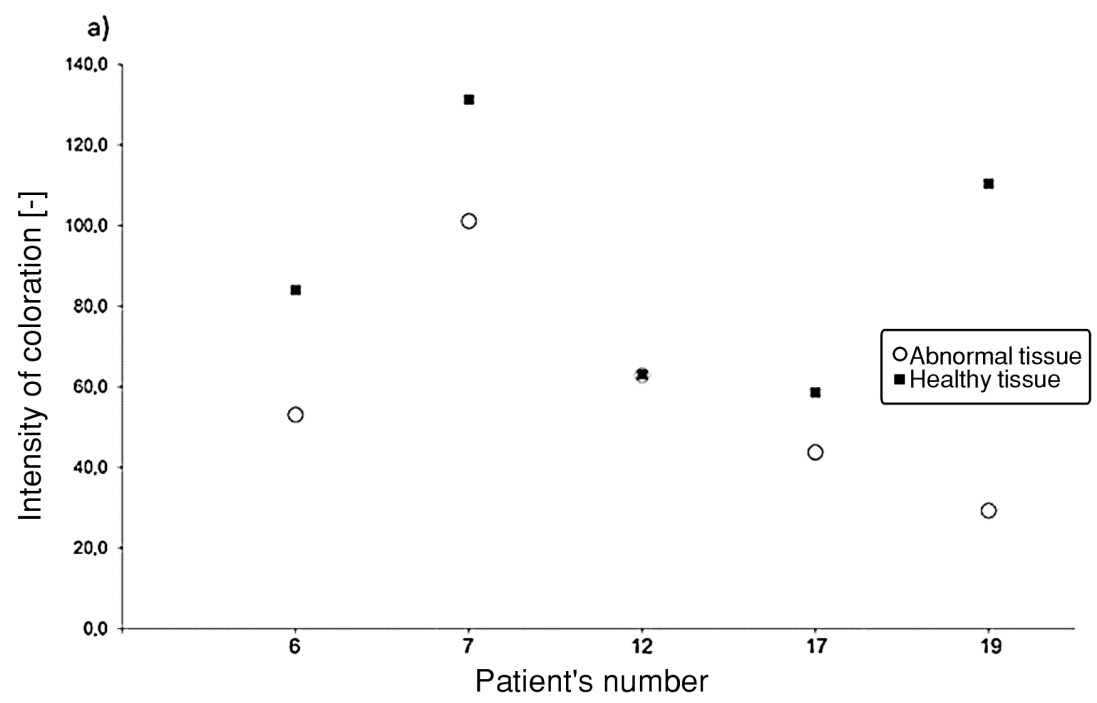

b)

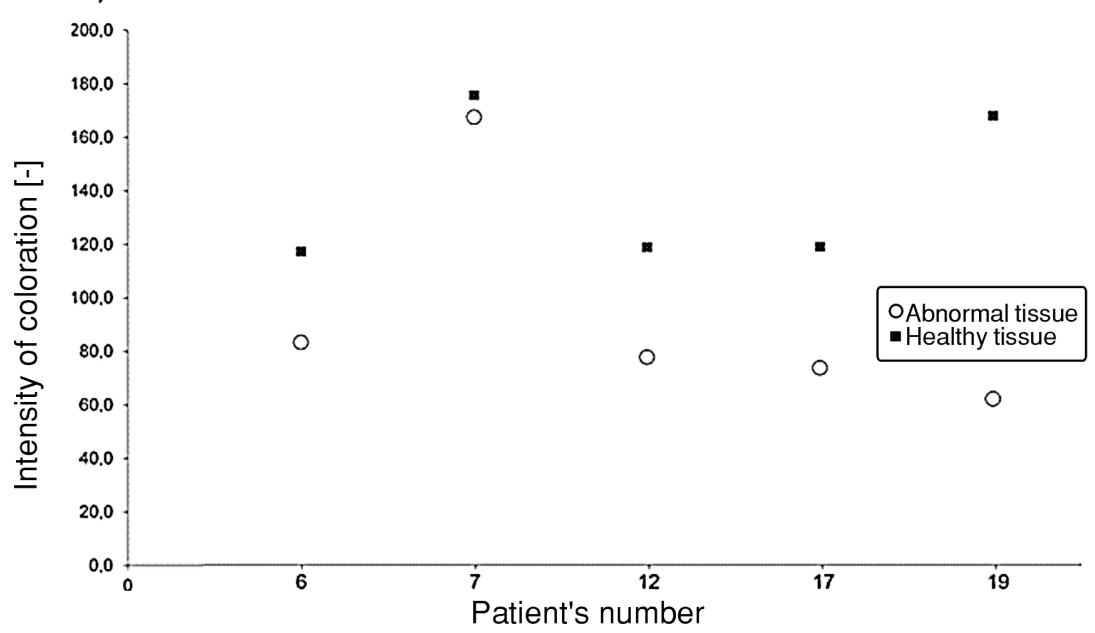

Figure 2. Scatter diagram for a) receptor 318A ( $N$-ricinoleyl-Trp-Pro- $\mathrm{NH}_{-} \mathrm{C}_{6} \mathrm{H}_{4}-\mathrm{NH}-\mathrm{C}_{4} \mathrm{H}_{3} \mathrm{~N}_{3} \mathrm{O}$-cellulose); b) receptor $102 \mathrm{~A}$ ( $N$-ricinoleylPhe-Ala-NH- $\mathrm{C}_{6} \mathrm{H}_{4}-\mathrm{NH}-\mathrm{C}_{4} \mathrm{H}_{3} \mathrm{~N}_{3} \mathrm{O}$-cellulose) binding malignant, papillary thyroid cancer and healthy thyroid tissue homogenates collected after biopsy from patients $6,7,12,17,19$. Each point presents the median from 3 measurements 
intensity of coloration was observed in the case of abnormal tissue compared to healthy tissue for $N$-ricinoleyl-Asp-Pro- $\mathrm{NH}-\mathrm{C}_{6} \mathrm{H}_{4}-\mathrm{NH}-\mathrm{C}_{4} \mathrm{H}_{3} \mathrm{~N}_{3} \mathrm{O}$-cellulose (compound 312A), whereas for compound 203A ( $N$ ricinoleyl-Leu-Trp-NH- $\mathrm{C}_{6} \mathrm{H}_{4}-\mathrm{NH}-\mathrm{C}_{4} \mathrm{H}_{3} \mathrm{~N}_{3} \mathrm{O}$-cellulose) color intensity was 4.5 -fold higher in the case of abnormal tissue in comparison to normal tissue. For 4 molecular receptors, the variation in the intensity of coloration in grayscale was close to $4(3.7,3.8)$. These constructs were all peptides lipidated with stearic acid residue: -Trp-Pro- (318B), -Gln-Pro(313B), -Met-Trp- (206B) and -Asn-Ala- (114B).

For the remaining types of benign cancers, Hürthle cell adenoma (Fig. 1b), Thyroiditis chronica (Fig. 1c) and Nodular goiter (Fig. 1d), as well as for malignant Papillary thyroid cancer (Fig. 1e), the differences in coloration were not as high as those for struma nodosa (multinodular goitre). Therefore, in all cases, the data were analyzed when there was a greater than 1.5-fold difference between the staining of healthy and cancerous tissues.

For benign Hürthle cell adenoma (Fig. 1b), this standard was fulfilled by 9 molecular receptors. The sharpest difference in intensity (2.8-fold) was for $\mathrm{N}$ stearoyl-Arg-Trp-NH- $\mathrm{C}_{6} \mathrm{H}_{4}-\mathrm{NH}-\mathrm{C}_{4} \mathrm{H}_{3} \mathrm{~N}_{3} \mathrm{O}$-cellulose (219B). For $N$-ricinoleyl-His-Ala- $\mathrm{NH}-\mathrm{C}_{6} \mathrm{H}_{4}-\mathrm{NH}-$ $\mathrm{C}_{4} \mathrm{H}_{3} \mathrm{~N}_{3} \mathrm{O}$-cellulose (115A) and $N$-stearoyl-Lys-Ala$\mathrm{NH}-\mathrm{C}_{6} \mathrm{H}_{4}-\mathrm{NH}-\mathrm{C}_{4} \mathrm{H}_{3} \mathrm{~N}_{3} \mathrm{O}$-cellulose (116B), the differences in color intensity were 2.5 and 2.4 , respectively, but both structures showed greater ability to bind to ligands in healthy tissue. It appears that, in the case of benign Hürthle cell adenoma, the key factor for distinguishing cancer tissue from healthy tissue is the presence of a basic amino acid residue in the peptide fragment of the molecule receptors. Molecular receptors containing -Leu-Ala-, -GluAla- and -Arg-Pro- $N$ - lipidated by ricinoleyl residue showed 2-fold higher ability to bind to ligands in healthy tissue as opposed to abnormal tissue.

For benign thyroiditis chronica (Fig 1c), a 1.5fold difference between $\mathrm{I}_{\mathrm{D}} \mathrm{h} / \mathrm{I}_{\mathrm{D}}{ }^{\mathrm{c}}$ was found in the case of 56 molecular receptors. Ten of these differed only in terms of the structure of the fatty acid residue: 102, 103, 106, 117, 118, 120, 214, 215, 218, 309, 318 and 320. A value for $I_{D}{ }^{h} / I_{D}{ }^{c}$ exceeding 5 was observed in the case of compound 118A ( $N$-ricinolyl-Trp-Ala-NH- $\mathrm{C}_{6} \mathrm{H}_{4}-\mathrm{NH}-\mathrm{C}_{4} \mathrm{H}_{3} \mathrm{~N}_{3} \mathrm{O}$-cellulose). Smaller, but still more than 3.5-fold differences, were observed for 117B ( $N$-stearoyl-Pro-Ala-NH$\mathrm{C}_{6} \mathrm{H}_{4}-\mathrm{NH}-\mathrm{C}_{4} \mathrm{H}_{3} \mathrm{~N}_{3} \mathrm{O}$-cellulose) and 106B (Nstearoyl-Met-Ala-NH- $\mathrm{C}_{6} \mathrm{H}_{4}-\mathrm{NH}-\mathrm{C}_{4} \mathrm{H}_{3} \mathrm{~N}_{3} \mathrm{O}$-cellulose). For structures 301A, 306B, 309B, 318B and $320 B$ the $I_{D}{ }^{h} / I_{D}{ }^{c}$ ratio was only 2 -fold higher. All of these compounds contained the proline residue as a
$C$-terminal amino acid, while the $N$-terminal amino acids were hydrophobic charge-free amino acid residues (Ala, Met, Thr, Trp, Gly).

In the case of lesions classified based on histopathology as benign nodular goiter (Fig. 1d), the criterion for differentiation of healthy tissue and cancerous tissue was fulfilled by 16 molecular receptors. Most of these were molecular receptors lipidated by (9Z, 12R)-12-hydroxyoctadec-9-enoic acid (ricinoleic acid) (A) (11 structures in the $\mathrm{A}$ series, and 5 compounds in the $\mathrm{B}$ series). The $\mathrm{I}_{\mathrm{D}}{ }^{\mathrm{h}} / \mathrm{I}_{\mathrm{D}}{ }^{\mathrm{c}}$ or $\mathrm{I}_{\mathrm{D}}{ }^{\mathrm{c}} / \mathrm{I}_{\mathrm{D}}{ }^{\mathrm{h}}$ observed for $\mathrm{N}$-stearoyl-Tyr-Ala-NH- $\mathrm{C}_{6} \mathrm{H}_{4}$ $\mathrm{NH}-\mathrm{C}_{4} \mathrm{H}_{3} \mathrm{~N}_{3} \mathrm{O}$-cellulose (109B), $N$-ricinolyl-CysTrp-NH- $\mathrm{C}_{6} \mathrm{H}_{4}-\mathrm{NH}-\mathrm{C}_{4} \mathrm{H}_{3} \mathrm{~N}_{3} \mathrm{O}$-cellulose (207A) and $\mathrm{N}$-stearoyl-Lys-Pro-NH- $\mathrm{C}_{6} \mathrm{H}_{4}-\mathrm{NH}-\mathrm{C}_{4} \mathrm{H}_{3} \mathrm{~N}_{3} \mathrm{O}$-cellulose (316B) were differentiated by a factor of 2 .

As shown in Figure 6e, in the case of malignant papillary thyroid cancer the $\mathrm{I}_{\mathrm{D}}{ }^{\mathrm{c}} / \mathrm{I}_{\mathrm{D}}{ }^{\mathrm{h}}$ of 13 molecular receptors was differentiated by a factor of at least 1.5. In all cases, the intensity of coloration was higher for cancer tissue. The sharpest differences in coloration (at least 2-fold higher) were observed for $\mathrm{N}$-stearoylTyr-Ala-NH- $\mathrm{C}_{6} \mathrm{H}_{4}-\mathrm{NH}-\mathrm{C}_{4} \mathrm{H}_{3} \mathrm{~N}_{3} \mathrm{O}$-cellulose (109B), $\mathrm{N}$ stearoyl-Asp-Ala-NH- $\mathrm{C}_{6} \mathrm{H}_{4}-\mathrm{NH}-\mathrm{C}_{4} \mathrm{H}_{3} \mathrm{~N}_{3} \mathrm{O}$-cellulose (112B) and $N$-stearoyl-Arg-Pro-NH- $\mathrm{C}_{6} \mathrm{H}_{4}-\mathrm{NH}$ $\mathrm{C}_{4} \mathrm{H}_{3} \mathrm{~N}_{3} \mathrm{O}$-cellulose (319B). In these 3 selected structures, none of the peptides contained tryptophan residue (aromatic amino acid) as a $C$-terminal amino acid, so it seems that the presence of a small hydrophobic amino acid is optimal for interaction with ligands. This seems to be generally true for this malignant tumor because in the pool of 13 selected molecular receptors only 2 contained tryptophan in the $C$-terminal position (204B and 210B). Given the structure of the $N$-terminal amino acid residue of the peptide fragment in the three selected structures, (109B), (112B) and (319B), it seems that the key factor is the capacity to form hydrogen bonds with interacting ligands. In this position were, respectively, tyrosine, aspartic acid and arginine residues.

From the point of view of practical utility, the most interesting molecular receptors are those with the ability to differentiate cancerous tissue from healthy tissue in all patients suffering from a particular type of cancer. Finding such structures would enable the preparation of a diagnostic test that could be used directly in the operating field (on-line analysis), improving decision-making during surgical interventions. Such a diagnostic tool would provide an additional test, supplementing standard histopathological analysis. With this aim in mind, a statistical analysis was performed on the staining data obtained from samples of tumorous and healthy tissue from 5 patients suffering from malignant papillary thyroid cancer. 
The Student's t-test for independent variables and the Student's t-test for dependent variables were used to find the differences between the means of the samples, and to establish the causal relationship. If there were differences between the measured mean values, then it could be assumed that the meanings were related to qualitative changes. This is the decisive factor for division into groups. The Student's t-tests revealed two structures that differentiated the homogenate of healthy tissue from diseased tissue homogenate and diagnosed most effectively the 5 cases of malignant, papillary thyroid cancer (Figs. $2 \mathrm{a}$ and $\mathrm{b}$ ).

The best differentiation between healthy and cancer tissue of patients suffering from malignant, papillary thyroid cancer was found for 102A ( $N$-ricinoleyl-Phe-Ala-NH- $\mathrm{C}_{6} \mathrm{H}_{4}-\mathrm{NH}-\mathrm{C}_{4} \mathrm{H}_{3} \mathrm{~N}_{3} \mathrm{O}$-cellulose), with a confidence interval of $\mathrm{p}<0.05$. The fact that $\mathrm{I}_{\mathrm{D}}{ }^{\mathrm{h}}>\mathrm{I}_{\mathrm{D}}{ }^{\mathrm{c}}$ indicates that the receptors bind more efficiently to markers present in healthy tissue than to the cancerous tissue homogenate, while more abundant markers are characteristic for cancer.

\section{CONCLUSIONS}

Given the numerous studies and large quantities of data documenting the differing composition of healthy and cancerous tissues, building a library of molecular receptors has vast potential as a new diagnostic tool. The diversity between particular cancer types includes metabolomic variation and other divergences caused by the composition of the individual metabolites of patients. In our study, even with a randomly-designed library of molecular receptors, it was possible to select two binding pockets: 318A ( $N$-ricinoleyl-Trp-Pro-NH- $\mathrm{C}_{6} \mathrm{H}_{4}-\mathrm{NH}-$ $\mathrm{C}_{4} \mathrm{H}_{3} \mathrm{~N}_{3} \mathrm{O}$-cellulose) and 102A ( $\mathrm{N}$-ricinoleyl-PheAla-NH- $\mathrm{C}_{6} \mathrm{H}_{4}-\mathrm{NH}-\mathrm{C}_{4} \mathrm{H}_{3} \mathrm{~N}_{3} \mathrm{O}$-cellulose) as valuable for diagnosing malignant papillary thyroid cancer. Although the complex nature of the responses caused significant problems with data-mining, the approach paves the road for personalized diagnostics and is highly promising from the point of view of monitoring the progress of cancer therapy. Moreover, this approach offers the possibility of developing a less invasive diagnostic method, using of readily accessible bodily fluids (urine, saliva, blood). Further research is already underway to identify structures of bounded ligands and those eliminate the main weakness of proposed method.

\section{Acknowledgement}

This work was supported by the Polish Ministry of Science and Education Poland no. N N405
669540 and by Lodz University of Technology grant no. RNB/WFS/9/2014.

\section{REFERENCES}

1. Torre L.A., Bray F., Siegel R.L., Ferlay J., Lortet-Tieulent J., Jemal A.: CA Cancer J. Clin. 65, 87 (2015).

2. La Vecchia C., Malvezzi M., Bosetti C., Garavello W., Bertuccio P. et al.: Int. J. Cancer 136, 2187 (2015).

3. Davies L., Welch H.G.: JAMA 295, 2164 (2006).

4. Horn-Ross P.L., Lichtensztajn D.Y., Clarke C.A., Dosiou C., Oakley-Girvan I. et al.: Cancer Epidemiol. Biomarkers Prev. 23, 1067 (2014).

5. Rahib L., Smith B.D., Aizenberg R., Rosenzweig A.B., Fleshman J.M., Matrisian L.M.: Cancer Res. 74, 2913 (2014).

6. Bosetti C., Bertuccio P., Malvezzi M., Levi F., La Vecchia C., Negri E.: Ann. Oncol. 24, 2657 (2013).

7. Holyoke E.D., Block G.E., Jensen E., Sizemore G.W., Heath H. et al.: Curr. Probl. Cancer 6, 1 (1981).

8. Whitley R.J., Ain K.B.: Clin. Lab. Med. 24, 29 (2004).

9. Gupta M., Chia S.Y.: Curr. Opin. Endocrinol. Diabetes Obes. 14, 383 (2007).

10. Makki F.M., Taylor S.M., Shahnavaz A., Leslie A., Gallant J. et al.: J. Otolaryngol. Head Neck Surg. 42, 16 (2013).

11. Yuxia F., Linan S., Qiuliang L., Rui D., Qian Z. et al.: Mol. Cancer 8, 79 (2009).

12. Shang X., Zhong X., Tian X.: Tumor Biol. 37, 11163 (2016).

13. Gill K.S., Tassone P., Hamilton J., Hjelm N., Luginbuhl A. et al.: J. Thyroid Disord. Ther. 5, doi:10.4172/2167-7948.1000200 (2016).

14. Wojakowska A., Chekan M., Widlak P., Pietrowska M.: Int. J. Endocrinol. Article ID 258763, dx.doi.org/10.1155/2015/258763 (2015).

15. Grogan R.H., Mitmaker E.J., Clark O.H.: Cancers 2, 885 (2010).

16. Wojakowska A., Chekan M., Marczak Ł., Polański K., Lange D. et al.: Mol. Cell. Endocrinol. 417, 149 (2015).

17. Guenther U.L.: Pathobiology 82, 153 (2015).

18. Kratky J., Vitkova H., Bartakova J., Telicka Z., Antosova M. et al.: Physiol. Res. 63, 263 (2014)

19. Hsiao S.J., Nikiforov Y.E.: Endocr.-Relat. Cancer. 21, 301 (2014).

20. Muluneh M., Issadore D.: Adv. Drug Deliv. Rev. 66, 101 (2014). 
21. Brazhnik K.I., Baryshnikova M.A., Sokolova Z.A., Nabiev I.R., Sukhanova A.V.: Ross. Bioterap. Zh. 12, 11 (2013).

22. Yip L.: J. Surg. Oncol. 111, 43 (2015).

23. Verdegem D., Moens S., Stapor P., Carmeliet P.: Cancer Metab. 2, 19 (2014).

24. Ribas V., García-Ruiz C., Fernández-Checa J.C.: Clin. Transl. Med. 5, 22 (2016).

25. Sancho P., Barneda D., Heeschen C.: Br. J. Cancer 114, 1305 (2016).

26. Beloribi-Djefaflia S., Vasseur S., Guillaumond F.: Oncogenesis 5, e189 (2016).

27. Yang M., Liu P., Huang P.: Tumour Biol. 37, 5735 (2016).

28. Justus C.R., Sanderlin E.J., Yang L.V.: Int. J. Mol. Sci. 16, 11055 (2015).

29. Villa E., Ricci J.E.: FEBS J. 283, 2653 (2016).

30. Boroughs L.K., De Berardinis R.J.: Nat. Cell Biol. 17, 351 (2015).

31. Yizhak K., Gaude E., Le Dévédec S., Waldman Y.Y., Stein G.Y. et al.: eLife 3, elife03641 (2014).
32. Zhao Y., Butler E.B., Tan M.: Cell Death Dis. 4, 1 (2013).

33. Zhou W., Liotta L.A., Petricoin E.F.: Cancer Genom. Proteom. 9, 373 (2012).

34. Lewis J.M., Heineck D.P., Heller M.J.: Expert Rev. Mol. Diagn. 15, 1187 (2015).

35. Larijani B., Perani M., Alburai'si K., Parker P.J.: Ann. N.Y. Acad. Sci. 134, 1 (2015).

36. Cantor J.R., Sabatini D.M.: Cancer Discov. 2, 1 (2012).

37. Soukup V., Kalousova M., Capoun O., Sobotka R., Breyl Z. et al.: Urol. Int. 95, 56 (2015).

38. Cairns R.A., Harris I.S., Mak T.W.: Nat. Rev. Cancer. 11, 85 (2011).

39. Frączyk J., Malawska B., Kamiński Z.J.: J. Comb. Chem. 11, 446 (2009).

40. Frączyk J., Mrozek A., Kamiński Z.J.: Bioelectrochem. 80, 2, (2010).

41. Frączyk, J., Kamiński Z.J.: J. Comb. Chem. 10, 934 (2008).

42. Frączyk J., Kolesińska B., Kamiński Z.J.: Arkivoc. 4, 186 (2012).

Received: 15.07. 2107 